Article

\title{
Analysis of Height-to-Width Ratio of Commercial Streets with Arcades Based on Sunshine Hours and Street Orientation
}

\author{
Xianfeng Huang ${ }^{1,2, * \mathbb{D}}$, Congmin $\mathrm{Li}^{1,2}$ and Zhixiang Zhuang ${ }^{1}$ \\ 1 College of Civil Engineering and Architecture, Guangxi University, Nanning 530004, China; \\ licongmin@st.gxu.edu.cn (C.L.); gxuzzx@163.com (Z.Z.) \\ 2 Guangxi Key Laboratory of Disaster Prevention and Engineering Safety, Guangxi University, Nanning 530004, \\ Guangxi, China \\ * Correspondence: x.f.huang@gxu.edu.cn
}

Citation: Huang, X.; Li, C.; Zhuang, Z Analysis of Height-to-Width Ratio of Commercial Streets with Arcades Based on Sunshine Hours and Street Orientation. Appl. Sci. 2021, 11, 1706. https://doi.org/10.3390/app11041706

Academic Editor: Constantinos

A. Balaras

Received: 25 December 2020

Accepted: 9 February 2021

Published: 14 February 2021

Publisher's Note: MDPI stays neutral with regard to jurisdictional claims in published maps and institutional affiliations.

Copyright: (c) 2021 by the authors. Licensee MDPI, Basel, Switzerland. This article is an open access article distributed under the terms and conditions of the Creative Commons Attribution (CC BY) license (https:// creativecommons.org/licenses/by/ $4.0 /)$.

\begin{abstract}
By extracting and simplifying the characteristics of commercial streets with arcades (Qilou) in Nanning, the tissue map of Qilou streets which reflects the urban morphology, including the road network form, block scale, building scale and other characteristics in a hot and humid area is obtained. In addition, the sunshine simulation is performed by using sunshine design software in an environment comprising streets with arcades to simulate street sunlight environments under various conditions. The relationship among street height-to-width ratio, sunshine hours, and street orientation angle is achieved by nonlinear fitting analysis. Then, a model is established to adjust the street height-to-width ratio based on sunshine requirement and street orientation. The finding indicated that when the street is north-south, it is suggested that the street height-to-width ratio is 0.95-1.13 to reduce sunshine hours effectively, and when the street is east-west, it is proposed that one side of the street should have a recessed space to improve the thermal conditions. The results of this study can serve as the specific guidelines that can be adopted in the redesign and reformation of commercial streets with arcades to achieve thermal comfort of Qilou streets in hot and humid areas.
\end{abstract}

Keywords: Qilou street; height-to-width ratio; sunshine hours; street orientation

\section{Introduction}

Streets are the basic organizational units of urban structure and city life, and the patterns of the streets affect their thermal environment. Solar radiation, street heightto-width ratio, orientation, and other urban morphology features affect the thermal environment [1-5]. Creating a comfortable thermal environment for streets is one of the demands and significant goals for forming virtuous city-pattern organizations [6]. The thermal environment of a commercial street in a city is formed under the combined effect of many factors, among which solar radiation is the most important in affecting the outdoor thermal environment and is the main motivation for adjusting the microclimate and thermal energy balance of streets. From the perspective of planning and design, the parameters (such as height-to-width ratio, etc.) of streets can be easily recognized by designers. Understanding the relationships among the parameters such as the height-to-width ratio of buildings along a street, sunshine hours and street orientation will enable improved thermal environments to be incorporated into city design and planning.

Sufficient sunshine is essential for humans. However, excessive sunshine in summer will likely cause overheating and will deteriorate the environment in street. Strong and direct solar radiation with long-wave thermal radiation from the building facades and the underlying surface of the block results in people feeling unbearably hot. On the streets, the mean radiation temperature $\left(T_{\mathrm{mrt}}\right)$ of each surface, which is the main decisive factor of outdoor human thermal comfort, is closely associated with solar and long-wave radiations. Furthermore, long-wave radiations are affected by local shading, air temperature, air humidity, and wind speed [7]. Hence, sunshine analysis is necessitated in the design of the 
thermal environment for the buildings in the street, with sunshine hours being the decisive factor for the intensity of solar radiation received by streets in the city. Hence, by setting the height-to-width ratios of the streets to generate shaded areas reasonably, the sunshine hours can be adjusted appropriately.

There have been several studies conducted by scholars regarding the effect of solar radiation based on the geometry of urban streets. Gong et al. [8] used Google Street View images to characterize street geometry and quantify solar irradiance on streets of highdensity urban regions in Hong Kong. Li [9] discovered that building height and effective greening significantly reduced the heat gain from ground thermal radiation, thereby improving the thermal environment of residential areas. He found that the increase of building height by $18 \mathrm{~m}$ reduces the radiation heat gain on the ground by about $20 \mathrm{~W} / \mathrm{m}^{2}$, which is mainly due to the increase of the shadow area of the buildings, and the growth of arbor tree coverage from $30 \%$ to $45 \%$ can bring about a decrease in the intensity of urban heat island of about $0.25^{\circ} \mathrm{C}$ and an average SET ${ }^{*}$ drop of about $1{ }^{\circ} \mathrm{C}$. Leng et al. [10] classified the street types of residential districts in Harbin based on thermal comfort using a combination of field measurements and simulations. Furthermore, under the urban climate in cold regions, they proposed that the urban morphology optimization strategy is a north-south street with a low height-to-width ratio, with values that are between 0.5-1.0 on both sides of the streets. The urban morphology also has an effect on outdoor air temperature. Yu et al. [11] established models by extracting seven urban morphology parameters from a geographical information system (GIS) map. The models can provide some accurate planning suggestions for urban heat island mitigation (UHI). Nowadays, UHI effect has become one of the major hazards in cities, Ronchi et al. [12] developed a cooling capacity model in the city of Milan to reduce heatwaves and UHI effect by setting urban design parameters and criteria. Because the decrease of the solar radiation is significant to energy saving for cooling, the impact of design factors of urban features on mitigating solar radiation was investigated by Bahgat et al. [13]. They found that varying the height-to-width ratio in linear types of urban open-spaces has the greatest influence in decreasing total solar radiation gained by surrounding buildings facades. The implications of this study are that street height-to-width ratio can be determined by controlling solar radiation, since Qilou street is also a linear type of urban open-space.

By now, few studies have been performed on urban open-spaces' thermal comfort in southern China [14]. Nanning is located in a hot summer and warm winter zone. As the urban commercial block, the commercial value and prosperity of Qilou street largely depends on outdoor thermal comfort in this region. In summer, commercial streets with arcades (Qilou) are crowded and hot. Excessive solar radiation will deteriorate the thermal environment of the streets, directly affecting people's shopping experience and reducing commercial profits. In order to enhance the commercial and tourism value of urban commercial pedestrian street, Ma et al. [14] studied the thermal comfort conditions in the microclimate of the street; then, some strategies were proposed to improve thermal comfort: increasing the building height, adding tree canyon coverage, and changing paving material. The relationship between urban geometry and microclimate has significantly influences the thermal comfort of individuals. Martinelli et al. [15] presents a long term numerical analysis of the effect of height/width proportions on the thermal comfort of courtyard typology. The results of the study reveal that high height/width proportions appear to have a stabilizing effect on thermal comfort. Ali-Toudert et al. [16] deals with the dependence of outdoor thermal comfort on the design of an urban street, including complex street geometry, orientation, greening coverage, etc. The results of the study indicated that if these factors are appropriately combined, it can effectively reduce heat stress in the summer and enhance thermal comfort. Among all the factors, sunshine-hours, morphology, pavements, greening and trees are the evident factors affecting the thermal environment of Qilou streets. Therefore, based on setting the height-to-width ratio of the streets reasonably, the sunshine hours of the streets on hot days can be minimized to create a pleasant street environment, improving residents' thermal comfort and shopping 
experience. Hence, the relationship between the planning characteristics of a block at a location and sunshine hours must be determined; in other words, a sunshine-hour model should be built up based on the planning characteristics of the block. According to the definition of sunshine hours by the World Meteorological Organization (WMO) [17], if the sunshine-hours are regulated in urban environment design, then the amount of solar radiation received by a location during that duration will be controlled to a certain extent [18]. This is critical to the optimization of the outdoor thermal environment through reasonable planning and design. In this regard, Ångström [19] proposed a sunshine-hours model; subsequently, Rietveld [20] proposed a functional relationship between the coefficients in Ångström's model and the percentage of sunshine. Based on the characteristics of the local climate, the sunshine-hours model was developed into a nonlinear model: Newland [21] introduced a logarithmic function into the model. Bakirci [22] proposed an exponential model for sunshine hours. All these models performed well as predictors of solar radiation from sunshine hours but the non-linear models were better than the basic linear model [23]. In order to obtain a more accurate sunshine-hours model, Ogelman [24] presented a quadratic nonlinear sunshine-hours model. Then, Bahel et al. [25] further developed a cubic nonlinear model based on Ogelman's model. The sunshine-hours models have become increasingly complex, improving their regional applicability and calculation accuracy. Almorox et al. [26] used some equations to calculate global solar radiation from sunshine hours for 16 meteorological stations in Spain. These equations involved the original Ångström-Prescott linear regression and modified functions (quadratic, third degree, logarithmic and exponential functions), it finds that the third degree models performed better than the other models, and the linear model is preferred due to its simplicity and application. In other words, high-order nonlinear sunshine-hours models can be applied in various regions [27]. Meteorological parameter models such as sunshine-hours models, therefore, are primarily used to calculate the amount of radiation [28]. Furthermore, a new method for estimating sunshine hours, like using remote sensing data, is emerging based on data from sunrise to sunset obtained from the Fengyun-2G geostationary meteorological satellite. Zhu et al. [29] proposed a method to calculate sunshine hours according to the total hourly cloud data between sunrise and sunset, which can accurately capture the spatial variation of the sunshine hour. As available solar radiation measured data do not meet the needs of Qilou street redesign, by analyzing the sunshine conditions on summer days for Qilou streets in the traditional commercial area of Nanning, this study explores the relationship among street height-to-width ratio, sunshine hours and street orientation, since it greatly influences the thermal comfort and UHI mitigation of urban commercial block herein. Additionally, an optimization strategy for commercial block replanning based on sunshine hours and street orientation is proposed.

This study was achieved by (i) analyzing the application of sunshine hour in the thermal environment design of the commercial streets by reviewing the available literatures (Section 1); (ii) describing the characteristics of the thermal environment and sunshine in Qilou commercial Street (Section 2); (iii) establishing a model to predict the street height-towidth ratio based on the sunshine hours and street orientation (Section 3); (iv) discussing the influences of the Qilou street pattern on sunshine hours and proposing optimization strategy to the street height-to-width ratio (Section 4); and (v) making the conclusions of this study.

\section{Thermal and Sunshine Environment in Qilou Streets}

Nanning (see Figure 1a) still retains the traditional streets from a hundred years ago, i.e., arcade buildings, namely Qilou, in the Lingnan Region. The traditional commercial block with arcades in Nanning is located in the Chaoyang district-the commercial center of Nanning, whose scope is shown in Figure $1 \mathrm{~b}$ (within red line area). The area of street with arcades measures approximately 25.92 hectares. Among them, the traditional commercial Qilou streets, "three streets and two lanes" area, represented by Xingning Road and Minsheng Road, etc., (see the blue line range in Figures $1 \mathrm{~b}$ and 2) in the traditional old 
blocks that are the most prosperous. As a thriving business center, there are few tree-plants on the streets of Xingning Road and Minsheng Road, with only some potted plants for beauty there. In these streets, the air temperature in the summer is directly affected by long-wave radiations, which are associated closely with sunshine hours and solar radiation intensity. Nanning, located in a hot and humid area, suffers from long sunshine duration in the summer; resulting in continuous high air temperatures in some areas of Qilou streets (see Figure 3). These areas are characterized simultaneously by the higher amounts of sunshine hours (about $8 \mathrm{~h}$ in sunny day) and low wind speed (less than $1 \mathrm{~m} / \mathrm{s}$ ) which generate the low-thermal comfort areas with $63.8 \%$ of average relative humidity and $34.4^{\circ} \mathrm{C}$ of mean radiant temperature.

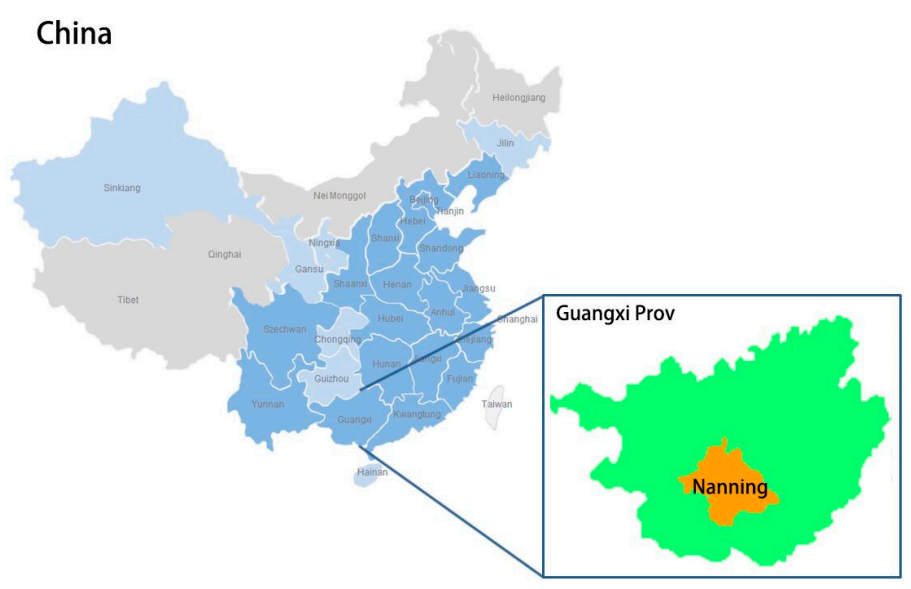

(a)

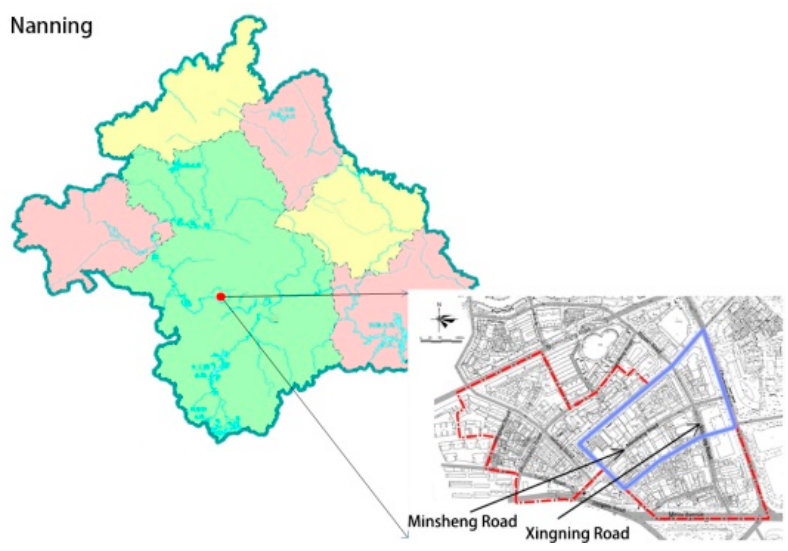

(b)

Figure 1. Geographical position of (a) Nanning in China and (b) scope of Qilou streets in Nanning.

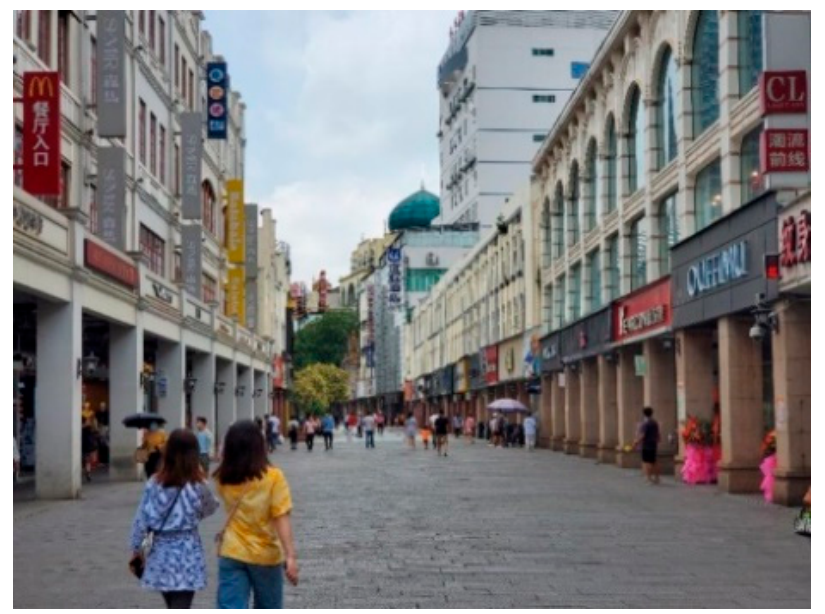

(a)

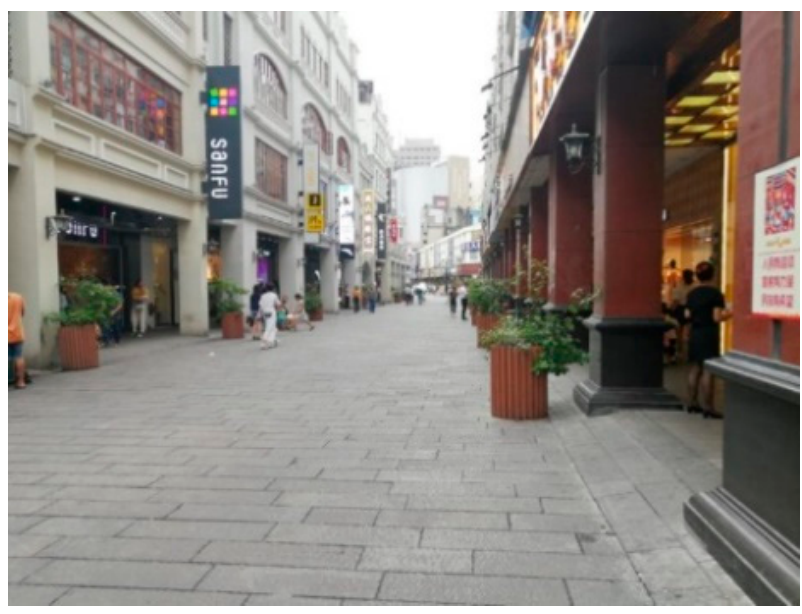

(b)

Figure 2. Qilou streets in Nanning: (a) Minsheng Road; (b) Xingning Road. 


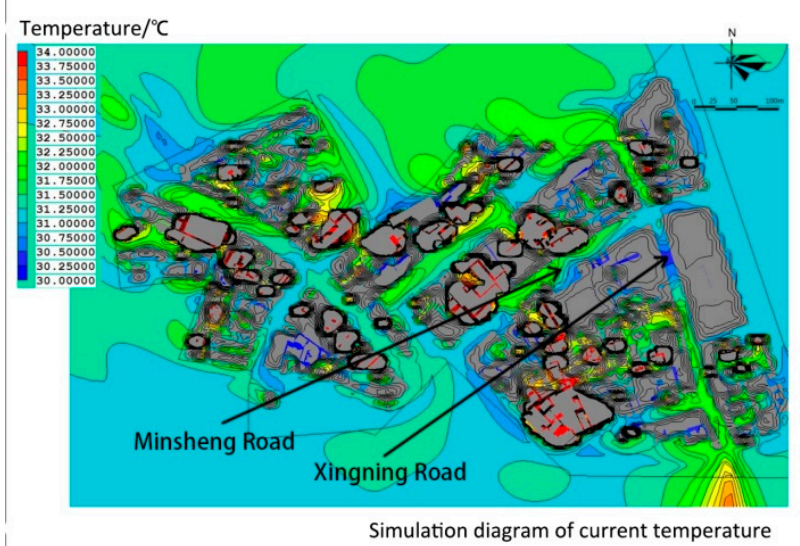

Figure 3. Temperature distributions for Qilou street area.

For the purpose of displaying the urban morphology, the road tissue map of Minsheng Road and Xingning Road, as shown in Figure 4, is drawn by taking the representative street orientation, width, length, building story height, storeys and width as the modeling data. The goal of this study is to investigate the reduction of solar radiation, that may be achieved by deciding the adequate design configurations of the urban block. Based on the air temperature distribution in the summer in Qilou streets in Nanning, it is evident that the underlayer surface conditions of these traditional streets are diverse as shown in Figure 4. The streets and lanes coincide with each other in complex manners. The radiation conditions vary significantly by morphology, greening, and pavements of the street, resulting in considerable differences in solar radiation intensity. Due to long sunshine duration, strong solar radiation, poor ventilation, and excessive high building density, in some Qilou streets such as Minsheng Road and Xingning Road, several areas have developed higher air temperature and have greatly increased the energy requirement for cooling and have a reduced thermal comfort in the microclimate.

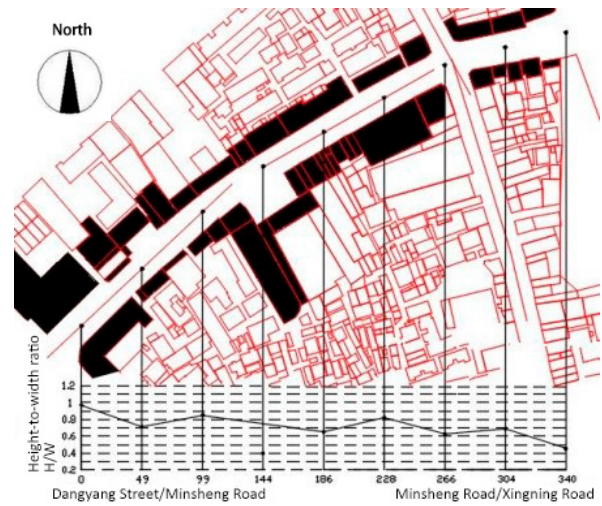

(a)

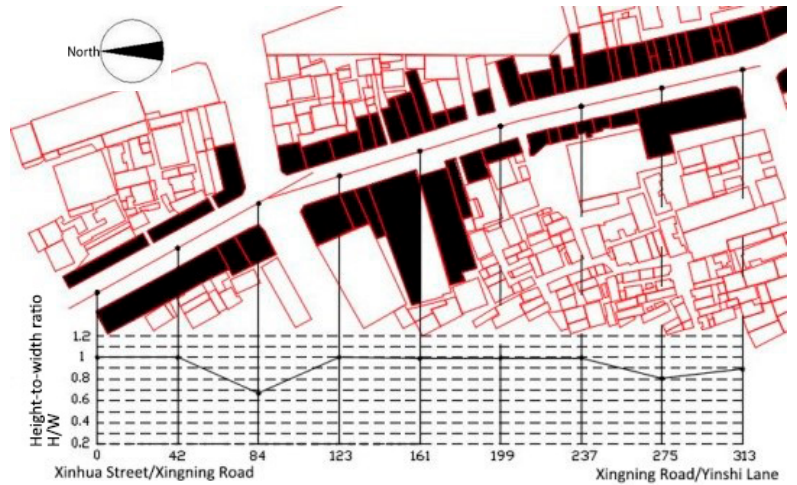

(b)

Figure 4. Urban tissue of (a) Minsheng Road and (b) Xingning Road.

\section{Methods and Analysis}

The definition of duration of possible sunshine by the WMO refers to that without any shade; in other words, the sum of time when sunlight irradiates the ground, where the sun passes from the eastern horizon to the western horizon of a certain area [17]. In the northern hemisphere, the duration of possible sunshine in the summer generally increases with the latitude, whereas in the winter, it decreases with the increase in the latitude. The sunshine hours is the sum of time during which direct solar irradiance intensity reaches or 
exceeds $120 \mathrm{~W} / \mathrm{m}^{2}$ in a certain area. The actual sunshine hours of solar radiation received on the ground is less than the number of possible sunshine hours, which is due to the occlusion of clouds and mist in the sky, and the various degrees of sun-shading caused by urban morphology and greening. As a consequence, sunshine hours are often used instead of possible sunshine hours in solar radiation models. Furthermore, the sunshine hours is the most commonly used parameter [30]. However, the global solar radiation which reflects the sunshine condition in a block environment can be calculated from sunshine hours [26]. In addition, the sunshine-hours model is the most widely used meteorological parameter model, and has the most accurate calculation results and the most accessible data among global solar radiation models [31]. According to the actual size of the buildings in the Qilou streets, Figure 5 shows the simulation of sunshine on Xingning Road and Minsheng Road by using software Ladybug, which is green building analysis software based on a parameterized design frame. The simulation time is at 8:00 16:00 on 22 June, the Summer Solstice, and the grid size is set to 1 .

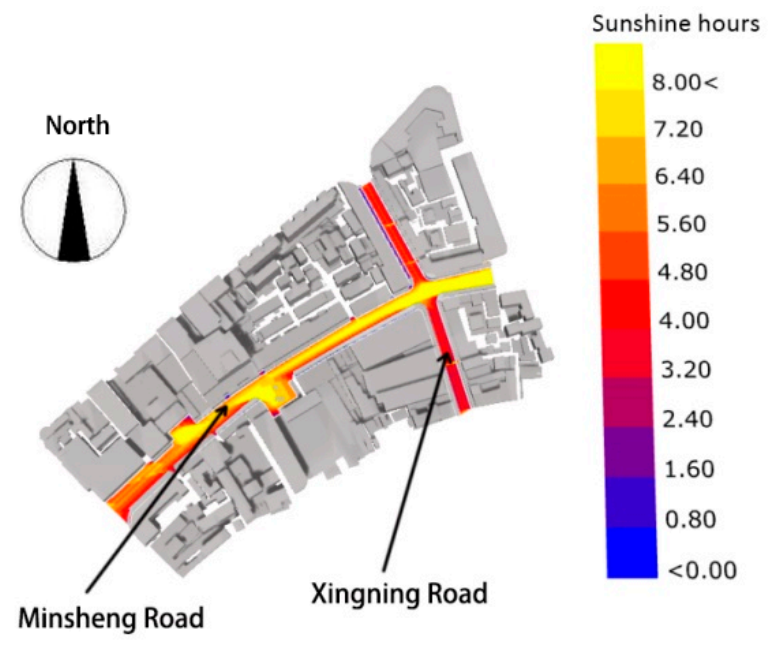

Figure 5. Distribution of sunshine hours on Xingning Road and Minsheng Road.

The street scale parameters refer to street orientation, width, length, building height and depth, all of which affect sunshine hours directly. Therefore, it is necessary to explore prediction methods and optimization strategies pertaining to the height-to-width ratio of commercial Qilou streets being affected by sunshine hours. The effects of street scale parameters on sunshine hours for Qilou streets, namely Xingning Road and Minsheng Road, which elevation is $77 \mathrm{~m}$, will be investigated:

(1) The street orientation angle: Minsheng Road spans from $43^{\circ}$ Northeast to $29^{\circ}$ Northeast, whereas Xingning Road spans from $119^{\circ}$ Northeast to $73^{\circ}$ Southeast. In this study, the initial direction of the street is the East-West direction which was set to $0^{\circ}$

(2) Street width: the street width of the pedestrian street or mall ranged from 9 to $13 \mathrm{~m}$.

(3) Street length: the pedestrian streets were partitioned by some branches of roads. The continuous building was $90-130 \mathrm{~m}$ long.

(4) Building level height: the level height of the building along the sides of the pedestrian street was $2.7-4 \mathrm{~m}$. Hence, the level height was set to $3.3 \mathrm{~m}$ in the sunshine model.

(5) Number of building levels: Figure 6 shows that the distribution of building storeys along the sides of the pedestrian street ranges from 1 to 9 . Both the level heights and number of levels determine the heights of the buildings. The effects of building height and street orientation on street sunshine hours are shown in Figures 7 and 8, respectively. The heights increased or decreased in proportion to the average height of actual architectural complexes. 


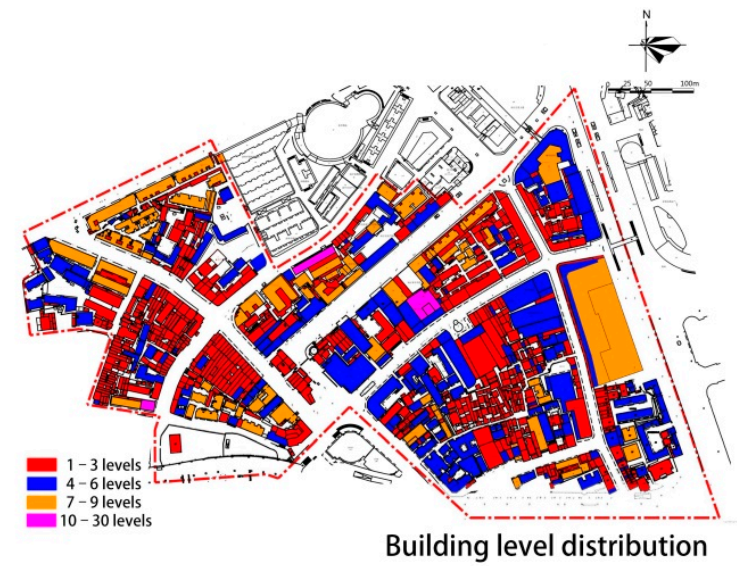

Figure 6. Building level distributions in Qilou streets area.

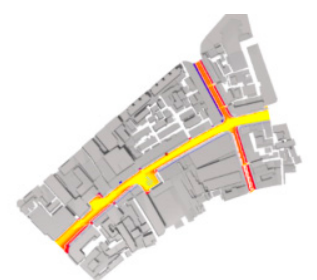

(a)

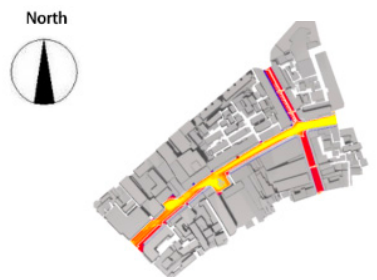

(b)

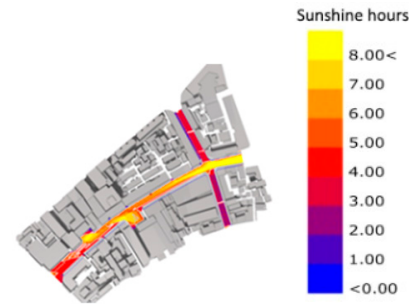

(c)

Figure 7. Sunshine analysis with different heights: (a) 2/3 of set value; (b) set value; (c) 1.5 times of set value.

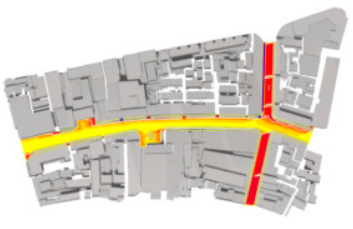

(a)

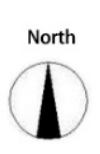

(b)

Figure 8. Sunshine analysis with different street orientations: (a) street orientation rotated $30^{\circ}$ clockwise; (b) street orientation rotated $60^{\circ}$ clockwise.

Creating a comfortable environment in street design requires not only the consideration of a single parameter, but also the comprehensive consideration of the scale parameters and psychological perception of the street. For building height $H$ and street width $W$, Yoshinobu [32] believed that when $H / W<1$, people feel more detached as the ratio decreases. When the ratio is less than 0.5 , people tend to feel that the street is spacious; when $H / W>1$, people prone to feel intimate as the ratio increases; when $H / W=1$, a symmetrical feeling between height and width is perceived. However, the architectural design application must be considered when defining $H / W$. The streets of some Italian medieval cities had $H / W \approx 2$, where the narrow streets formed a new scenery; in the Renaissance, to improve the order and aesthetic effects of urban streets, it was generally believed that streets with equal height and width would be ideal; however, in the Baroque period, to pursue magnificent effects, the width of many streets were constructed as twice the building height such that the spatial composition of the buildings can be fully appreciated. The Qilou streets in Nanning exhibit a style that combines traditional architecture with modern commerce. If the street height-to-width ratio is excessively large, then the architectural pattern will not be beautiful enough. Meanwhile, the commercial demand requires the height-to-width ratio to be not too small. Hence, $H / W \approx 1$ is appropriate. Accurate radiation calculations in 
micro-environments and small-scale spaces such as urban blocks must be performed based on topography while considering the occlusion between buildings. Sunshine simulations must consider both model and environmental parameters. The model information is listed in Table 1.

Table 1. Parameters of sunshine model of Nanning commercial streets with arcades.

\begin{tabular}{ccc}
\hline Model Parameters & Value & Remarks \\
\hline Street orientation & $0^{\circ} \sim 90^{\circ}$ & $\begin{array}{c}\text { Setting the east-west direction as the initial value } \\
\text { and } 5^{\circ} \text { as the step size, shift to } 90^{\circ} \text { northward }\end{array}$ \\
\hline Street width & $10 \mathrm{~m}$ & - \\
\hline Street length & $100 \mathrm{~m}$ & - \\
\hline Level height of buildings & $3.3 \mathrm{~m}$ & - \\
\hline Number of levels of buildings & $1 \sim 10$ stories & $\begin{array}{c}\text { Setting } 1 \text { as the initial value and } 1 \text { as the step } \\
\text { size, increase to } 10 \text { levels }\end{array}$ \\
\hline Building width & $15 \mathrm{~m}$ & - \\
\hline
\end{tabular}

Meteorological parameter models such as the sunshine-hours model are primarily adopted to calculate the amount of radiation [18]. The data of the model's environment parameters such as the sunshine height, date, duration, standard, and precision were obtained from the "Technical Rules for Green Building Evaluation", [33] as shown in Table 2.

Table 2. Sunshine environment parameters of commercial Qilou streets in Nanning.

\begin{tabular}{ccc}
\hline Environmental Element & Value & Remarks \\
\hline Sunshine height & $0 \mathrm{~m}$ & - \\
\hline Sunshine location & Nanning & - \\
\hline Sunshine date & 22 June & - \\
\hline Sunshine hours & $8 \mathrm{~h}$ & - \\
\hline Sunshine standard & National standard & - \\
\hline Sunshine precision & Minute & \\
\hline
\end{tabular}

Based on the abovementioned parameter conditions, 180 sets of data were obtained. The points along the central line of Qilou street were used as the sunshine data log point. The statistical data under various conditions for sunshine hours, height-to-width ratio, and angle were acquired. The results are shown in Figure 9.

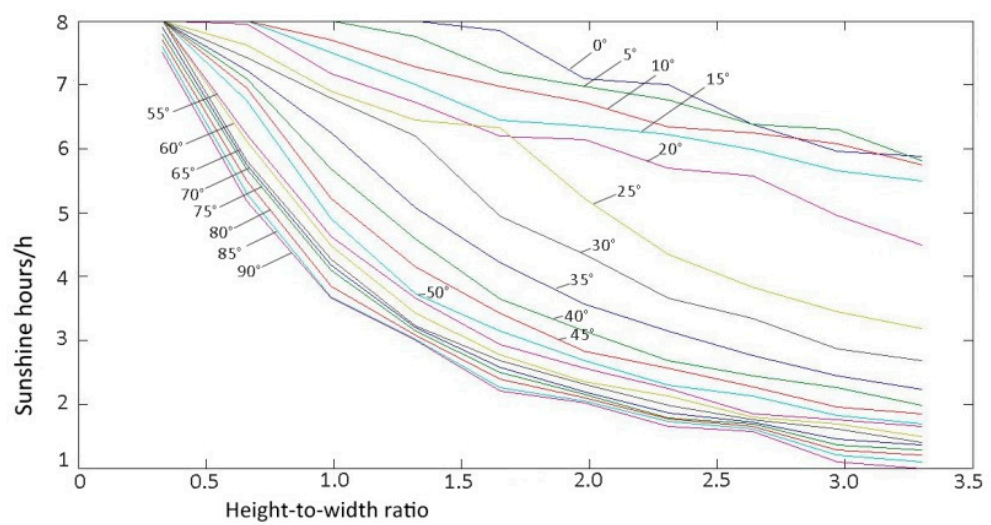

Figure 9. Relationship among height to width ratio, sunshine hours and street orientation in Qilou street area. 
The relationship between height-to-width ratio and sunshine hours under different orientations was analyzed. Figure 9 shows that as the height-to-width ratio decreased, the sunshine hours for the street increased exponentially; with the increase in the street orientation angle (setting $0^{\circ}$ as due east, and the north as the positive direction), and the sunshine hours decreased gradually. In other words, by fixing the other conditions, the closer the street orientation to the north-south direction, the shorter is the sunshine hours; furthermore, the higher the buildings on both sides of the street, the shorter is the sunshine hours. Because the first power approximation is the closest to the variation curve of the data, and the variation trend complies with the actual situation, so, it is indicated that exponential regression functions performed better than the others. The exponential regression was adopted to fit the height-to-width ratio and sunshine hours. The fitting expression is:

$$
y=a x^{b}
$$

where $x$ is the sunshine hours; $y$ is the height-to-width ratio; $a$ and $b$ are functions of the street orientation angle $\theta$. Table 3 shows the fitting results of street orientation and sunshine hours. As shown in Table 3 and Figure 9, when the coefficients $a$ and $b$ of the streets with orientation angles $25^{\circ}$ to $90^{\circ}$ were fitted, an exponential function was selected to fit the relationship between $a$ and $\theta$, as follows:

$$
a=d e^{f \theta}+g e^{h \theta}
$$

where $d, f, g$, and $h$ are constants. The fitted expression obtained is as follows:

$$
a=626 e^{-0.1653 \theta}+12.33 e^{-0.01408 \theta},
$$

\begin{tabular}{|c|c|c|c|c|c|c|}
\hline Street Orientation & $a$ & $b$ & Residual Sum of Squares & Fit & Modified Fit & Standard Deviation \\
\hline $0^{\circ}$ & 1780 & -3.542 & 1.497 & 0.8334 & 0.8125 & 0.4326 \\
\hline $5^{\circ}$ & 4568 & -4.046 & 1.023 & 0.8861 & 0.8718 & 0.3577 \\
\hline $10^{\circ}$ & 8610 & -4.451 & 0.4695 & 0.9477 & 0.9412 & 0.2422 \\
\hline $15^{\circ}$ & 4128 & -4.159 & 0.3335 & 0.9629 & 0.9582 & 0.2042 \\
\hline $20^{\circ}$ & 149.1 & -2.465 & 0.9209 & 0.8975 & 0.8847 & 0.3393 \\
\hline $25^{\circ}$ & 18.68 & -1.465 & 0.7248 & 0.9193 & 0.9092 & 0.301 \\
\hline $30^{\circ}$ & 12.59 & -1.33 & 0.4054 & 0.9549 & 0.9492 & 0.2251 \\
\hline $35^{\circ}$ & 9.284 & -1.251 & 0.2019 & 0.9775 & 0.9747 & 0.1589 \\
\hline $40^{\circ}$ & 7.902 & -1.232 & 0.1191 & 0.9867 & 0.9851 & 0.122 \\
\hline $45^{\circ}$ & 6.902 & -1.197 & 0.09127 & 0.9898 & 0.9866 & 0.1068 \\
\hline $50^{\circ}$ & 6.225 & -1.183 & 0.06195 & 0.9931 & 0.9922 & 0.088 \\
\hline $55^{\circ}$ & 5.819 & -1.179 & 0.0819 & 0.9909 & 0.9897 & 0.1012 \\
\hline $60^{\circ}$ & 5.321 & -1.15 & 0.04847 & 0.9946 & 0.9939 & 0.07784 \\
\hline $65^{\circ}$ & 4.982 & -1.13 & 0.04291 & 0.9952 & 0.9946 & 0.07323 \\
\hline $70^{\circ}$ & 4.612 & -1.097 & 0.04539 & 0.9949 & 0.9943 & 0.07532 \\
\hline $75^{\circ}$ & 4.282 & -1.044 & 0.08706 & 0.9903 & 0.9891 & 0.1043 \\
\hline $80^{\circ}$ & 4.015 & -1.009 & 0.1233 & 0.9863 & 0.9846 & 0.1241 \\
\hline $85^{\circ}$ & 3.72 & -0.9564 & 0.2044 & 0.9772 & 0.9744 & 0.1599 \\
\hline $90^{\circ}$ & 3.415 & -0.8825 & 0.2975 & 0.9669 & 0.9627 & 0.1929 \\
\hline
\end{tabular}

Table 3. Fitting results of street orientation and sunshine hours. 
The fitting results for $a$ and $\theta$ are shown in Table 4 . The relationship between $b$ and $\theta$ can be fitted using the following power function:

$$
b=i \theta^{k}+j
$$

where $i, j$, and $k$ are constants. The fitted expression gives:

$$
b=0.04979 \theta^{0.6254}-1.768 \text {. }
$$

Table 4. Fitting results for $a$ and $\theta$.

\begin{tabular}{cccc}
\hline Residual Sum of Squares & Fit & Modified Fit & Standard Deviation \\
\hline 0.05501 & 0.9998 & 0.9997 & 0.07417 \\
\hline
\end{tabular}

The fitting results for $b$ and $\theta$ are shown in Table 5. Then, the relationship among the height-to-width ratio $y$, sunshine hours $x$, and street angle $\theta$ is:

$$
y=\left(626 e^{-0.1653 \theta}+12.33 e^{-0.01408 \theta}\right) x^{\left(0.04979 \theta^{0.6254}-1.768\right)} .
$$

Table 5. Fitting results for $b$ and $\theta$.

\begin{tabular}{cccc}
\hline Residual Sum of Squares & Fit & Modified Fit & Standard Deviation \\
\hline 0.01876 & 0.9366 & 0.9251 & 0.0413 \\
\hline
\end{tabular}

\section{Optimization and Discussion}

Using the $4 \mathrm{~h}$ shadow proposed in the "Technical Rules for Green Building Evaluation" [33] as the evaluation objective, the curve in Figure 10 describes the relationship between the height-to-width ratio and the street orientation angle, as the daily sunshine hours is $4 \mathrm{~h}$.

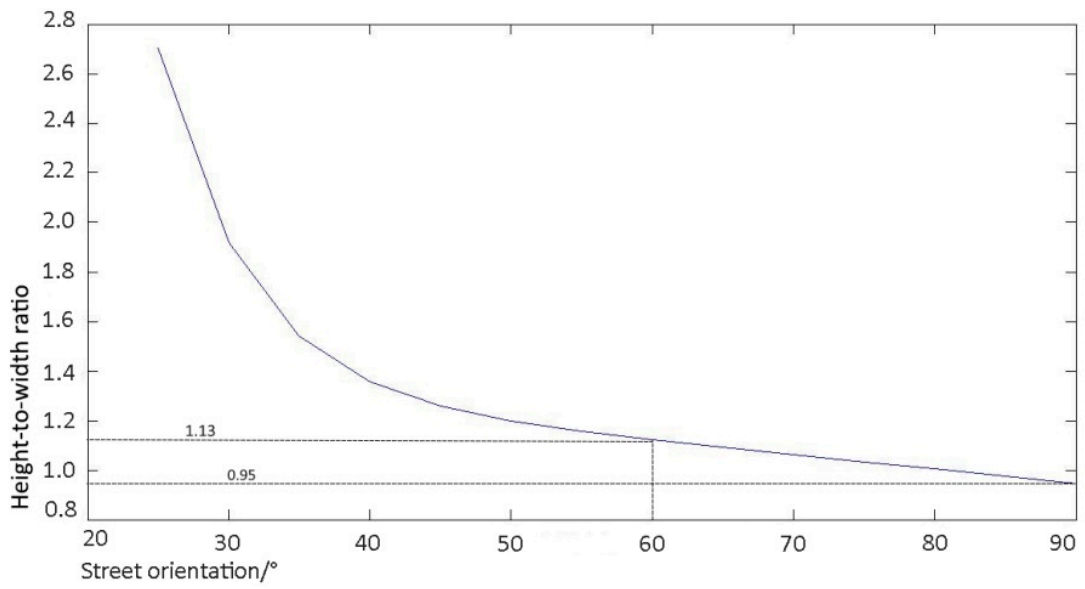

Figure 10. Relationship between height to width ratio and street orientation.

As shown in Figure 10, when the street orientation angle was $60^{\circ}-90^{\circ}$, a height-towidth ratio between 1.13-0.95 enables the street to maintain a reasonable sunshine duration. It is shown that when the street orientation angle exceeds $60^{\circ}$, the effect of height-to-width ratio on sunshine hours is greatly increased. When the street orientation angle is less than $30^{\circ}$, the influence of height-to-width ratio on sunshine hours will decrease sharply. A large height-to-width ratio is required to create sufficient shadows. However, an excessively large height-to-width ratio can create a sense of oppression and hence is not beneficial to constructing favorable streets. When the height-to-width ratio is 1, Figure 11 shows 
the relationship between sunshine hours and angle of street orientation. When the street orientation angle is less than $30^{\circ}$, the architectural shadow areas provided by variation the height-to-width ratio will reduce sharply. Hence, it is less meaningful to create shadows by adjusting the height-to-width ratio.

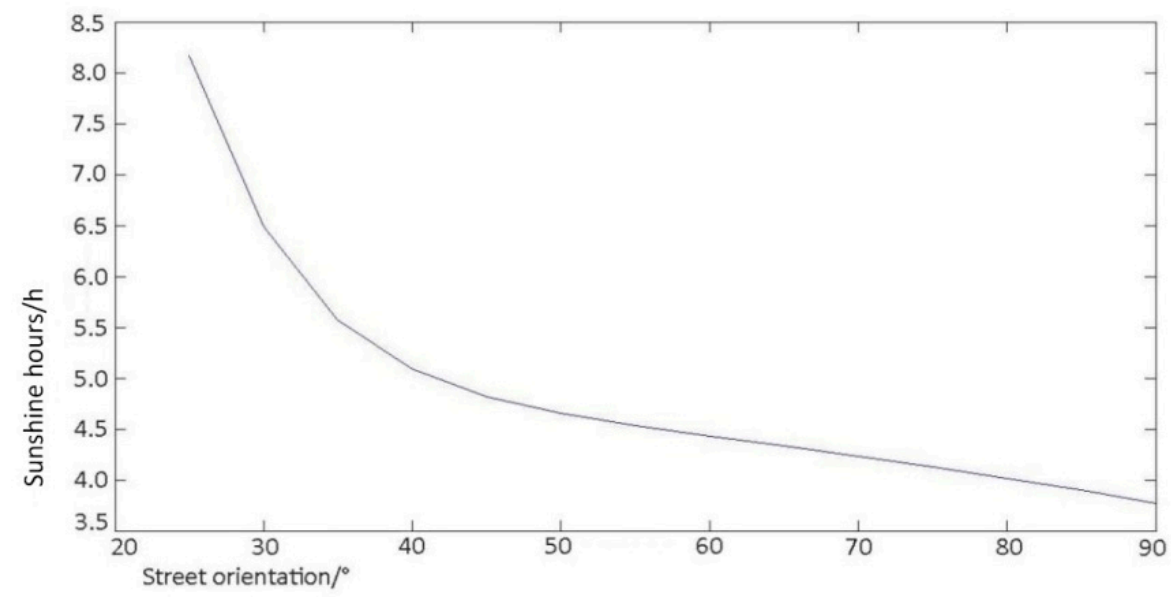

Figure 11. Relationship between sunshine hours and street orientation.

Considering the effects of street enclosure, street orientation, and height-to-width ratio on the sunshine environment, Qilou commercial streets in Nanning can be classified into three categories: streets spanning east-west to $30^{\circ}$ northeast are defined as streets in the east-west orientation; streets spanning north-south to $60^{\circ}$ northeast are defined as streets in the north-south orientation; streets spanning $30^{\circ}$ northeast to $60^{\circ}$ northeast are defined as streets in the northeast-southwest orientation. This paper will analyze the sunshine-hours prediction models of the streets in the first two categories.

For the north-south streets, the height-to-width ratio exhibits an evident influence on the sunshine hours. Favorable shadow area can be formed by adjusting the height-to-width ratio of Qilou street. The height-to-width ratio for the target value of sunshine hours can be obtained using the fitting expression to optimize the design. As shown in Figures 12 and 13 , after the street height-to-width ratio were 0.33 and 0.99 respectively, the sunshine hours in Qilou street decreased from $8 \mathrm{~h}$ to approximately $4 \mathrm{~h}$. It can be seen that the ratio of height to width has a significant effect on sunshine hours of the north-south street.
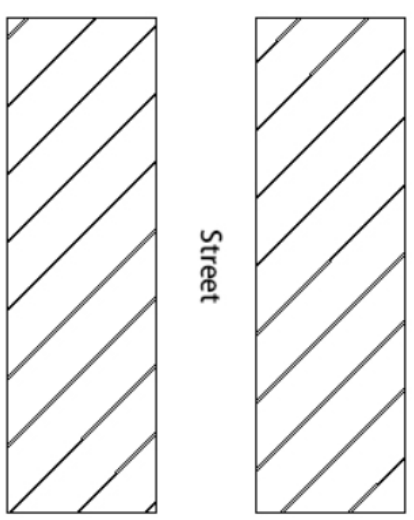

(a)

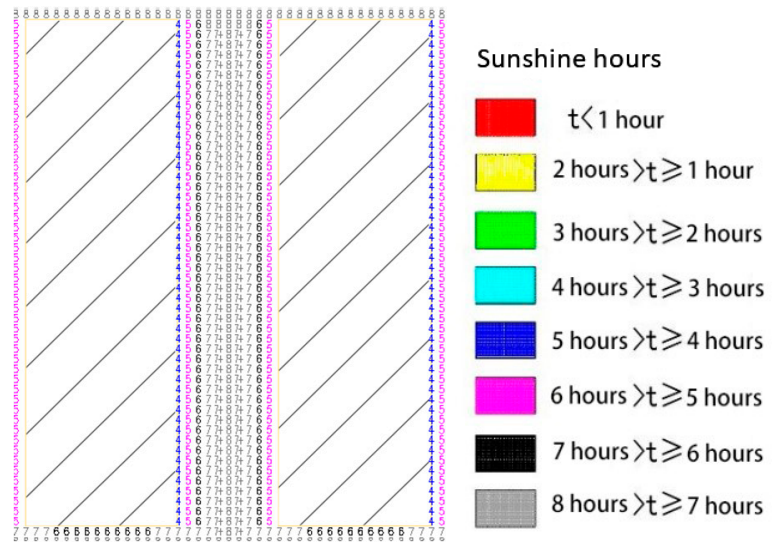

(b)

Figure 12. Height-to-width ratio of 0.33 in north-south street: (a) street plane; (b) distribution of sunshine hours. 

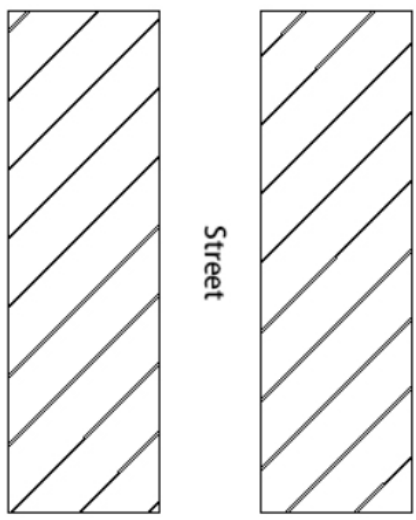

(a)

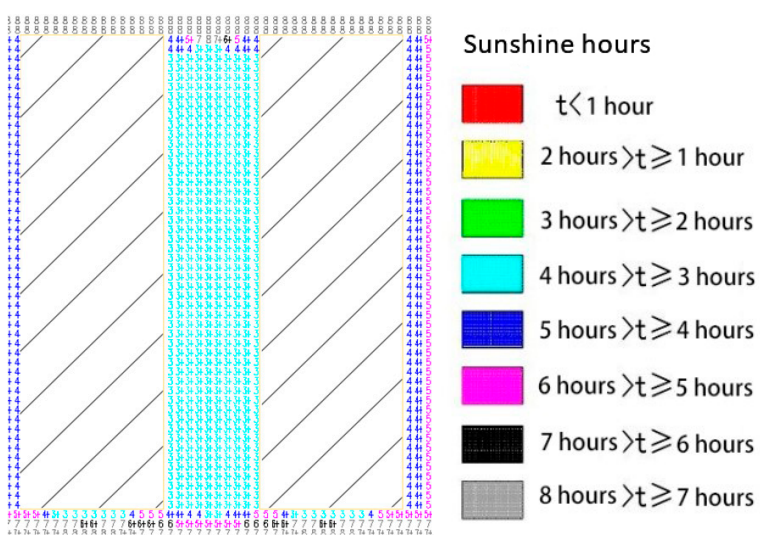

(b)

Figure 13. Height-to-width ratio of 0.99 in north-south street: (a) street plane; (b) distribution of sunshine hours.

The effects of an east-west street and an east-west street with a "recessed area" on sunshine hours are shown in Figures 14 and 15, respectively. For the east-west streets, the height-to-width ratio affected the sunshine hours less. Hence, it is not appropriate to increase the height-to-width ratio to create more shadow areas. Because the buildings on both sides contribute less to the increase in shadow area, more shadow areas can be created from the architectural pattern. According to environmental psychology theory [34], people generally prefer to rest on the edge of places, because having their backs against buildings helps them to maintain their private territory and enables them to observe the surrounding environment clearly. For example, the recessed space can be used to construct resting areas. The introduction of recessed space can be considered from the views of place design, promoting urban public life and citizen participation, so as to design comfortable space. The recessed space cannot be adopted in the north-south street because the recessed space will receive more solar radiation than that of other areas, thereby deteriorating the thermal environment. Figure 16 shows sunshine situation exhibited higher sunshine hours in the "recessed area" in a north-south street.

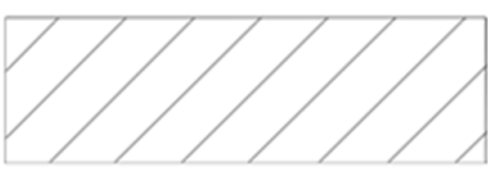

street

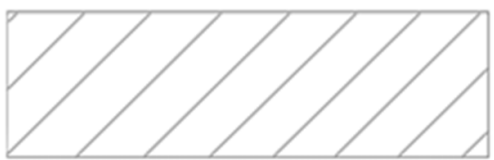

(a)

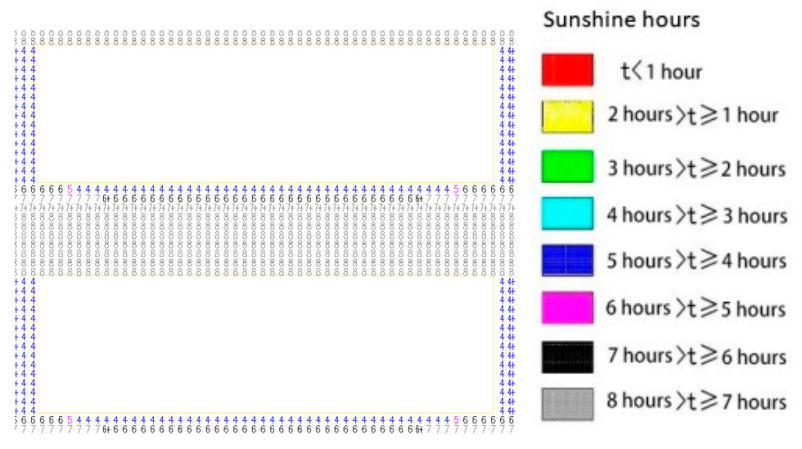

(b)

Figure 14. East-west street: (a) street plane; (b) distribution of sunshine hours. 

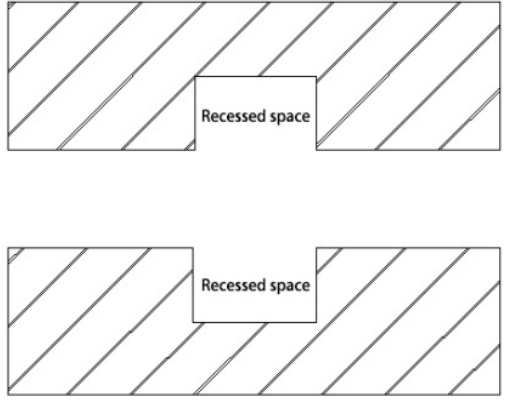

(a)

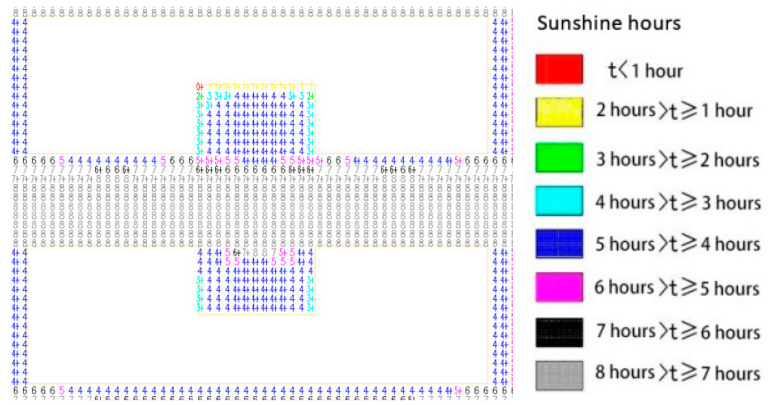

(b)

Figure 15. East-west street with "recessed area": (a) street plane; (b) distribution of sunshine hours.
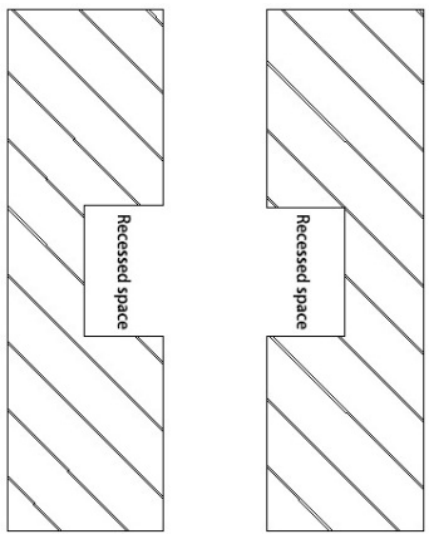

(a)

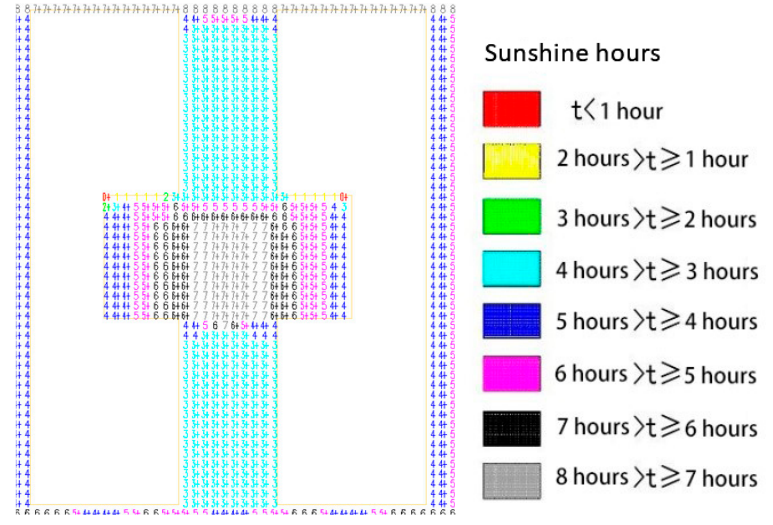

(b)

Figure 16. North-south street with "recessed area": (a) street plane; (b) distribution of sunshine hours.

For the construction of recessed space, the designer is generally concerned with the less sunshine hours in the recessed area, rather than hoping to give a more sunny area therein. Therefore, it is of guiding significance to understand the variation of sunshine in recessed space. With respect to the recessed space of an east-west street, the sunshine hours in the recessed space is determined by the building height, the size of recessed area, and street orientation angle. Hence, by regression Equation (6), the fitting expression for the height-to-width ratio varied with sunshine hours and street orientation angle in the recessed space can be obtained:

$$
y=\left[626 e^{-0.1653\left(90^{\circ}-\theta\right)}+12.33 e^{-0.01408\left(90^{\circ}-\theta\right)}\right] x^{\left[0.04979\left(90^{\circ}-\theta\right)^{0.6254}-1.768\right]} .
$$

Based on Equation (7), sunshine design can be performed on the recessed space of different street orientation to create more shadow region. In addition, some green landscape, recreation and drinking water facilities can be arranged to form a psychological centripetal space and comfortable resting places.

Comparing this research with other studies in the bibliographic review, the results of this study provide the urban designer with the effects of the design configurations of commercial blocks on reducing solar radiation. Additionally, optimization strategies of urban features are achieved under consideration of sunshine hours and street orientation. 


\section{Conclusions}

The relationship between urban features and microclimate is a hot topic in urban studies, since it has an enormous effect on the thermal comfort of urban blocks. This study investigates the method of solar radiation reduction that may be achieved by determining the favorable design factors of the urban block, Qilou street, and the non-linear regression model that was established.

Sunshine-hours is a dominant indicator of the solar radiation on the received area. So, it is also an important meteorological parameter for architectural design, urban planning, and landscape layout. Based on the analysis of the sunshine hours in the street by conducting computational simulation, it is found that the sunshine hours and the street orientation have a significant influence on the height-to-width ratio. By fitting the power function of height-to-width ratio, sunshine hours and street orientation angle, the relationship between the three parameters was determined. Consequently, an exponential model which determines the height-to-width ratio of Qilou street was developed. Through the analysis of the sunshine simulation of Qilou streets in Nanning, the optimal height-to-width ratio of the street can be determined from the required sunshine hours and the street orientation. The analysis revealed that when the street orientation angle was less than $30^{\circ}$, the effect of the height-to-width ratio on the sunshine hours decreased rapidly. At this moment, the street required a larger height-to-width ratio to reduce the sunshine hours to create an ideal thermal environment. However, this imposed a relatively strong sense of oppression in people. When the street orientation angle exceeded $60^{\circ}$, the effect of the height-to-width ratio on the sunshine hours increased sharply. Therefore, combined with the application requirements of Qilou commercial streets, the streets were classified into three categories: east-west, north-south, and northeast-southwest streets, based on their orientations. The design schemes were investigated based on the effect of the sunshine hours and street orientation angle on the height-to-width ratio. The results showed that:

(1) The north-south street is suitable for forming a large shadow area by using the high height-to-width ratio. When the ratio is $0.95-1.13$, the street sunshine hours decrease to less than $4 \mathrm{~h}$, thereby affording a more comfortable thermal environment.

(2) The adoption of recessed spaces is suitable on the east-west street to create a cool resting space in summer. The recessed spaces should be reasonably designed by using Equation (7).

(3) The northeast-southwest-oriented streets should organically combine height-to-width ratio and "recessed area" design methods to create a comfortable Qilou street environment based on actual urban morphology.

The model for predicting the relationship among the height-to-width ratio, sunshine hours, and street orientation established in this study can serve as a basis for the thermal environment design of traditional commercial streets in hot and humid areas.

Author Contributions: Conceptualization, X.H.; methodology, X.H.; investigation, X.H., C.L. and Z.Z.; writing, X.H., C.L. and Z.Z.; visualization, X.H., C.L. and Z.Z.; supervision, X.H.; project administration, X.H.; funding acquisition, X.H. All authors have read and agreed to the published version of the manuscript.

Funding: This research was funded by National Natural Science Foundation of China, grant number 51568003.

Institutional Review Board Statement: Not applicable.

Informed Consent Statement: Not applicable.

Data Availability Statement: The data presented in this study are available on request from the corresponding author.

Conflicts of Interest: The authors declare no conflict of interest. 


\section{References}

1. Jin, H.; Wang, B. A review of evaluation studies on urban micro-climate and thermal comfort. Build. Sci. 2017, 33, 1-8. (In Chinese)

2. Oke, T.R. Street design and urban canopy layer climate. Energy Build. 1988, 11, 103-113. [CrossRef]

3. Johansson, E. Influence of urban geometry on outdoor thermal comfort in a hot dry climate: A study in Fez, Morocco. Build. Environ. 2006, 41, 1326-1338. [CrossRef]

4. Rasul, A.; Balzter, H.; Smith, C. Spatial variation of the daytime surface urban cool island during the dry season in Erbil, Iraqi Kurdistan, from Landsat 8. Urban Clim. 2015, 14, 176-186. [CrossRef]

5. Lobaccaro, G.; Acero, J.A. Comparative analysis of green actions to improve outdoor thermal comfort inside typical urban street canyons. Urban Clim. 2015, 14, 251-267. [CrossRef]

6. Huang, Y.Q.; Sun, Y.M. Judgment characteristics and quantitative index of suitable block scale. J. South China Univ. Technol. (Nat. Sci. Ed.) 2012, 40, 131-138. (In Chinese)

7. Aminipouri, M.; Rayner, D.; Lindberg, F.; Thorsson, S.; Knudby, A.J.; Zickfeld, K.; Middel, A.; Krayenhoff, E.S. Urban tree planting to maintain outdoor thermal comfort under climate change: The case of Vancouver's local climate zones. Build. Environ. 2019, 158, 226-236. [CrossRef]

8. Gong, F.Y.; Zeng, Z.C.; Ng, E.; Norford, L.K. Spatiotemporal patterns of street-level solar radiation estimated using Google Street View in a high-density urban environment. Build. Environ. 2019, 148, 547-566. [CrossRef]

9. Li, C. Research on the Residential Thermal Environment Based on the Planning Factors. Master's Thesis, Tsinghua University, Beijing, China, 2012. (In Chinese).

10. Leng, H.; Ma, Y.H. A preliminary study on the street space patterns by applying microclimate thermal comfort zoning method. J. Harbin Inst. Technol. 2015, 47, 63-68. (In Chinese)

11. Yu, Z.; Chen, S.; Wong, N.H. Temporal variation in the impact of urban morphology on outdoor air temperature in the tropics: A campus case study. Build. Environ. 2020, 181, 107-132. [CrossRef]

12. Ronchi, S.; Salata, S.; Arcidiacono, A. Which urban design parameters provide climate-proof cities? An application of the Urban Cooling InVEST Model in the city of Milan comparing historical planning morphologies. Sustain. Cities Soc. 2020, 63, 102459. [CrossRef]

13. Bahgat, R.; Reffat, R.M.; Elkady, S.L. Analyzing the impact of design configurations of urban features on reducing solar radiation. J. Build. Eng. 2020, 32, 101664. [CrossRef]

14. Ma, X.; Fukuda, H.; Zhou, D.; Gao, W.; Wang, M. The study on outdoor pedestrian thermal comfort in blocks: A case study of the Dao He Old Block in hot-summer and cold-winter area of southern China. Sol. Energy 2019, 179, 210-225. [CrossRef]

15. Martinelli, L.; Matzarakis, A. Influence of height/width proportions on the thermal comfort of courtyard typology for Italian climate zones. Sustain. Cities Soc. 2017, 29, 97-106. [CrossRef]

16. Ali-Toudert, F.; Mayer, H. Effects of asymmetry, galleries, overhanging facades and vegetation on thermal comfort in urban street canyons. Solar Energy 2007, 81, 742-754. [CrossRef]

17. WMO-No. 8. Guide to Meteorological Instruments and Methods of Observation; Secretariat of the World Meteorological Organization: Geneva, Switzerland, 2014.

18. Wang, G.A.; Mi, H.T.; Deng, T.H. Calculation of the change range of the sun high angle and the azimuth of sunrise and sunset in one year. Meteorol. Environ. Sci. 2007, 30, 161-164. (In Chinese)

19. Ångström, A. Solar and terrestrial radiation. Q. J. R. Meteorol. Soc. 1924, 50, 121-125. [CrossRef]

20. Rietveld, M. A new method for estimating the regression coefficients in the formula relating solar radiation to sunshine. Agric. Meteorol. 1978, 19, 243-252. [CrossRef]

21. Newland, F.J. A study of solar radiation models for the coastal region of south China. Sol. Energy 1988, 31, 227-235. [CrossRef]

22. Bakirci, K. Correlations for estimation of daily global solar radiation with hours of bright sunshine in Turkey. Energy 2009, 34, 485-501. [CrossRef]

23. David, B.; Ampratwum, A.; Dorvlo, S.S. Estimation of solar radiation from the number of sunshine hours. Appl. Energy 1999, 63, 161-167.

24. Ogelman, H.; Ecevit, A.; Tasdemiroglu, E. A new method for estimating solar radiation from bright sunshine data. Sol. Energy 1984, 33, 618-625. [CrossRef]

25. Bahel, V.; Bakhel, H.; Srinivasan, R. A correlation of global solar radiation. Energy 1987, 12, 131-135. [CrossRef]

26. Almorox, J.; Hontoria, C. Global solar radiation estimation using sunshine duration in Spain. Energy Convers. Manag. 2004, 45, 1529-1535. [CrossRef]

27. Besharat, F.; Ali, A.; Dehghan, A.R. Empirical models for estimating global solar radiation: A review and case study. Renew. Sustain. Energy Rev. 2013, 21, 798-821. [CrossRef]

28. Sun, Z.A.; Shi, J.R.; Weng, D.M. A further research on the climatological calculation method of the global solar radiation over China. J. Nanjing Inst. Meteorol. 1992, 15, 21-28. (In Chinese)

29. Zhu, W.; Wu, B.; Yan, N.; Ma, Z.; Wang, L.; Liu, W. Estimating sunshine duration using hourly total cloud amount data from a geostationary meteorological satellite. Atmosphere 2020, 11, 26. [CrossRef]

30. Zhao, N.; Zeng, X.F.; Han, S.M. Solar radiation estimation using sunshine hour and air pollution index in China. Energy Convers. Manag. 2013, 76, 846-851. [CrossRef] 
31. Liu, D.L.; Yang, L.; Huo, X.J.; Liu, J.P. Review of globe solar radiation model for building energy efficiency analysis. J. Civil Archit. Environ. Eng. 2015, 37, 101-108. (In Chinese)

32. Yoshinobu, A. The Aesthetic Townscape; Yi, P.F., Translator; Baihua Literature and Art Publishing House: Tianjin, China, 2006.

33. Wang, Q.Q.; Han, J.H.; Zeng, J. Technical Rules for Green Building Evaluation 2019; China Architecture \& Building Press: Beijing, China, 2020. (In Chinese)

34. Edgerton, E. Environmental Psychology: Putting Research into Practice; Cambridge Scholars Publishing: Newcastle, UK, 2005. 